\title{
Bacteriological and Physiochemical Analysis of Oguta Lake Water, Imo State, Nigeria
}

\author{
Okorondu S. I. ${ }^{1, *}$, Anyadoh-Nwadike S. O. ${ }^{2}$ \\ ${ }^{1}$ Department of Microbiology, Federal University of Technology, Imo State, Nigeria \\ ${ }^{2}$ Department of Biotechnology, Federal University of Technology, Imo State, Nigeria
}

Email address:

sokorondu@yahoo.co.uk (Okorondu S. I.), sylanyad@yahoo.com (Anyadoh-Nwadike S. O.)

\section{To cite this article:}

Okorondu S. I., Anyadoh-Nwadike S. O. Bacteriological and Physiochemical Analysis of Oguta Lake Water, Imo State, Nigeria. Science Journal of Public Health. Special Issue: Who Is Afraid of the Microbes. Vol. 3, No. 5-1, 2015, pp. 14-19.

doi: $10.11648 /$ j.sjph.s.2015030501.13

\begin{abstract}
Bacteriological and Physiochemical analysis were carried out on Oguta lake water from three guage stations; upstream, midstream and downstream used for drinking and recreational purposes in Imo State, South-Eastern, Nigeria. The results obtained were compared with World health organisation (WHO) and Environmental protection agency (EPA) standards for drinking and recreational water respectively. The following parameters; conductivity (30.8 us $\backslash \mathrm{cm}$ ), colour (90.67 ptlco), iron $(0.47 \mathrm{mgl})$, lead $(0.18 \mathrm{mgl})$, cadmium $(0.08 \mathrm{mg} / \mathrm{l})$, nitrate $(0.9 \mathrm{ml})$ and odour (unpleasant) did not meet WHO standards while temperature $\left(30.8^{\circ} \mathrm{C}\right), \mathrm{pH}(5.71 \mathrm{cpu})$, total dissolved solids (TDS) $(73.87 \mathrm{mg} / \mathrm{l})$, total solids (TSS) (7 mg/l), turbidity (17 $\mathrm{ntu})$, phosphate $(0.19 \mathrm{mg} / \mathrm{l})$, sulphate $(0.19 \mathrm{mg} / \mathrm{l})$, manganese $(0.1 \mathrm{mg} / \mathrm{l})$ and appearance (clear) met the standards. None of the samples conformed to WHO and EPA bacteriological standards for total heterotrophic count of $1.0 \times 10^{-2}$ in $100 \mathrm{ml}$ of water, total coliform count and feacal coliform count of 1:100 $\mathrm{ml}$ of water for drinking and recreational water. Samonella, Shigella and Vibro cholera were not detected. The presence of coliforms in water for drinking and recreational purposes is of public health significance considering the possibilities of the presence of other bacteria, protozoa and enteric viruses that are implicated in gastro-intestinal water borne diseases and the low infectious dose of these water borne pathogens. Presence of chemicals in water is also of great concern, health effect from chemicals have been difficult to assess because the impact is not acute like that of pathogens, but often cumulatively resulting to cancer and sometimes death. The general public should be educated on dangers of contaminated water as well as prevention of indiscriminate dumping of domestic and industrial wastes into the lake.
\end{abstract}

Keywords: Water, Drinking, Recreational, Bacteriological, Physiochemical, Coliform

\section{Introduction}

Water is a clear colourless, odourless and tasteless liquid substance that falls as rain, fills lakes and rivers and is essential for life to exist $[1,2]$. It is one of the important natural resources useful for domestic and developmental purposes in both urban and rural areas [2]. Water analysis is carried out to ensure a safe water supply for various purposes; drinking, bathing, swimming, domestic and recreational activities. There are various methods used in analyzing water samples collected from a water body. The most important methods used in small community water supplies are the bacteriological, physical and chemical test.

Bacteriological analysis of water involves isolation and count of indicator organisms whose presence indicates that disease causing pollution has occurred in water supply. These "indicator" organisms are bacteria called coliform bacteria [4] Coliform bacteria describe a group of enteric bacteria that includes Eschericia coli, Klebsiella sp. and Enterobacter sp. They are Gram negative, facultatively anaerobic, non- sporing rods that may be motile. They are able to ferment lactose to produce acid and gas within $48 \mathrm{hrs}$ at $35^{\circ} \mathrm{C}$ [5]. Although they are generally not harmful themselves, they indicate the possible presence of pathogenic bacteria, viruses and protozoa [5]. Bacterial agents of concern are those that cause diarrhoea and gastroenteritis namely Salmonella sp. Shigella sp., Eschericia coli (E. coli) and Vibrio cholerae [6]. Protozoan agents that cause diarrhoea are Entamoeba histolytica, Glardia lambia, Balatidium coli [7] and Cryptococcus pervum [8]. Enteroviruses causing various clinical ailments not necessarily diarrhoea, but transmitted by water include poliovirus, 
rotavirus, Hepatitis A virus [9] and Hepatitis E. virus [10]. Coliform bacteria are easier to identify than other pathogens. Coliform levels are therefore used to determine the bacteriological quality of water.

Water bodies are contaminated through runoffs, sewage and agricultural wastes. These are usually high in organic matter and nutrient. Hence they could cause increase in the microbial flora of the water bodies, thereby resulting in high heterotrophic bacteria counts [11].

Physicochemical characteristics are vital for water quality monitoring [12]. The physiochemical tests include the determination of odour, appearance, taste, temperature, $\mathrm{pH}$, turbidity, conductivity, total dissolved solid and total suspended solids $[2,12]$.

Oguta lake is located at Oguta in Imo state, Nigeria. Its source from Njaba river while it discharges into Urasi river. People in this area depend on this lake for drinking, fishing, bathing and recreational activities. It is evident that human and even natural activities within and around the lake have the potential to alter its resource status and usefulness.

\section{Aim and Objective of Study}

This study was aimed at determining the bacteriological and physiochemical quality of Oguta lake, with a view to assessing its usefulness as portable/ recreational water and to recommend control measures where necessary.

\section{Materials and Method}

\subsection{Sample Collection}

Waters samples were collected with carefully washed and sterile non- reactive, transparent glass bottles of $500 \mathrm{ml}$ capacity. Samples were taken from the lake by holding the bottle near its base in the hand and plunging its neck downward below the water surface to a depth of 15 to $30 \mathrm{~cm}$. This was done at three gauge stations; the upstream (being the source of the river, Point A), midstream (Point B) and downstream (where the water and other debris are discharged, Point $\mathrm{C}$ ). The sampling bottle was not filled up to the brim, $20 \mathrm{~mm}$ to $30 \mathrm{~mm}$ space was left for effective shaking of the bottle [12]. The bottles were then labeled appropriately as follows;

Sample A - Up stream

Sample B - Mid stream

Sample C - Down stream

\subsection{Bacteriological Analysis}

These were carried out as described by $[12,13]$ as follows:

\subsubsection{Total Heterotrophic Count}

An aliquot $(0.1 \mathrm{ml})$ of the serial dilutions of $10^{-5}$ and $10^{-6}$ of each sample was inoculated in duplicates onto well labeled nutrient agar plates. Hockey stick which has been sterilized by dipping into alcohol and flaming was allowed to cool and used to spread the sample evenly on the respective agar surface.

\subsubsection{Total Coliform Count}

Aliquots, $0.1 \mathrm{ml}$ of $10^{-5}$ and $10^{-6}$ of each of the samples were inoculated in duplicates on each of the well labeled Mackonkey agar plates using the spread plate method. The plates were incubated at $37^{\circ} \mathrm{C}$ for $24 \mathrm{hrs}$.

\subsubsection{Samonella Shigella Count}

Aliquots $(0.1 \mathrm{ml})$ of $10^{-5}$ and $10^{-6}$ of each of the samples were inoculated in duplicate onto well labeled Salmonella Shigella agar plates using the spread plate and incubated at $37^{\circ} \mathrm{C}$ for $24 \mathrm{hrs}$.

\subsubsection{Vibro Count}

Aliquots $(0.1 \mathrm{ml})$ of $10^{-4}$ and $10^{-5}$ each of the samples were inoculated in duplicates onto well labeled thiosulfate citrate bile salt-sucrose agar using the spread plate method. These were incubated at $37^{\circ} \mathrm{C}$ for $24 \mathrm{hrs}$.

\subsubsection{Feacal Coliform Count (Membrane Filtration)}

This method is based on the use of highly porous cellulose membrane which will allow fairly large volume of water (e.g $100 \mathrm{ml}$ ) to pass through rapidly under pressure but prevents passage of bacteria. The bacteria which remain on the surface of the membrane are then cultured on Eosine methylene blue (EMB) agar plate. The viable count gives the presumptive number of coliforms in the $100 \mathrm{ml}$ water sample.

\subsection{General Isolation and Characterization of Bacteria from the Respective Water Samples}

Isolation and enumeration of bacteria from the respective samples was done using standard microbiological protocols on appropriate culture media; nutrient agar, mackonkey agar, eosine methylene blue agar, Salmonella Shigella agar, thiosulphate citrate bile salt sucrose. The pour plate method was used for culture. All plates were incubated at $37^{\circ} \mathrm{C}$ for $24 \mathrm{hrs}$. The colonies were counted and recorded as colony forming units per mililitre $(\mathrm{cfu} / \mathrm{ml})$. Subsequently the isolates were characterized and identified based on cultural/ morphological characteristics, Gram reactions and other standard biochemical tests as described by [13].

\subsection{Physiochemical Analysis}

The physiochemical tests included the determination of odour, colour, appearance, taste, temperature, $\mathrm{pH}$, total dissolved solids, total suspended solids, turbidity, nitrate phosphate, iron, lead, manganese, cadbium, sulphate, and nitrite contents. These were carried out using standard protocols [12]. The temperature was determined in situ by using the mercury in glass thermometer in centigrade scale the temperatures were taken by dipping the thermometer into $50 \mathrm{ml}$ of the water samples.

The $\mathrm{pH}$ was determined by using $\mathrm{pH}$ test strips in situ while suntex $\mathrm{pH}$ meter was used to check the $\mathrm{pH}$ ex situ. Electrical conductivity was determined using Wissen Schaffich Techiske conductivity meter. Turbidity of the samples was determined by using logging spectrophotometer at a wavelength of 860 $\mathrm{nm}$ and product number of 450 . 


\section{Results}

Table 1. Physiochemical parameters of Oguta Lake.

\begin{tabular}{lllll}
\hline Parameters & Samples A & Sample B & Sample C & Mean sample \\
\hline Temperature & 30.6 & 30.9 & 31.0 & 30.8 \\
pH & 5.49 & 5.87 & 5.76 & 5.71 \\
Conductivity & 234 & 58 & 49 & 113.7 \\
TDS & 152 & 37.7 & 31.9 & 73.87 \\
TSS & 0.0 & 12 & 9.0 & 9.0 \\
Colour & 123 & 47 & 102 & 17 \\
Turbidity & 26 & 14 & 11 & 0.97 \\
Nitrate & 0.9 & 0.9 & 0.8 & 0.19 \\
Phosphate & 0.50 & 0.04 & 0.02 & 2.0 \\
Sulphate & 2.0 & 1.0 & 2.0 & 0.47 \\
Iron & 0.46 & 0.45 & 0.50 & 0.18 \\
Lead & 0.15 & 0.15 & 0.25 & 0.1 \\
Manganese & 0.0 & 0.2 & 0.1 & 0.08 \\
Cadmium & 0.06 & 0.07 & 0.10 & clear \\
Appearance & clear & clear & clear & unpleasant \\
Odour & & unpleasant & unpleasant & \\
\hline
\end{tabular}

Table 2. Total heterotrophic bacterial counts.

\begin{tabular}{lllll}
\hline Samples used & No. of colonies $\mathbf{1 0}^{-5}$ & No. of colonies $\mathbf{1 0}^{-\mathbf{6}}$ & $\begin{array}{l}\text { Total counts obtained } \\
\text { Cfu/ml }\end{array}$ & $\begin{array}{l}\text { Total counts obtained } \\
\text { Cfu/ml }\end{array}$ \\
\hline Sample A & 7 & 4 & $7 \times 10^{6}$ & $4 \times 10^{7}$ \\
Sample B & 10 & 6 & $1 \times 10^{7}$ & $6 \times 10^{7}$ \\
Sample C & 13 & 8 & $1.3 \times 10^{7}$ & $3.35 \times 10^{7}$ \\
\hline
\end{tabular}

Table 3. Total coliform bacterial counts $(\mathrm{Cfu} / \mathrm{ml})$.

\begin{tabular}{llll}
\hline \multirow{2}{*}{ Samples } & Total counts & & Plate 2 \\
\cline { 2 - 3 } & Plate 1 & $1 \times 10^{7}$ & $6.5 \times 10^{6}$ \\
\hline Sample A & $3 \times 10^{6}$ & $2 \times 10^{7}$ & $1.25 \times 10^{7}$ \\
Sample B & $5 \times 10^{6}$ & $1.1 \times 10^{8}$ & $5.75 \times 10^{7}$ \\
Sample C & $8 \times 10^{6}$ & average counts & \\
\hline
\end{tabular}

Table 4. Total feacal coliform counts per $100 \mathrm{ml}$.

\begin{tabular}{ll}
\hline Samples & Escherichia coli \\
\hline Sample A & 5 \\
Sample B & 18 \\
Sample C & 11 \\
\hline
\end{tabular}

Sample A- Up stream; $\quad$ Sample B - Mid stream; $\quad$ Sample C - Down stream

Table 5. Salmonella, Shigella and Vibrio cholera count.

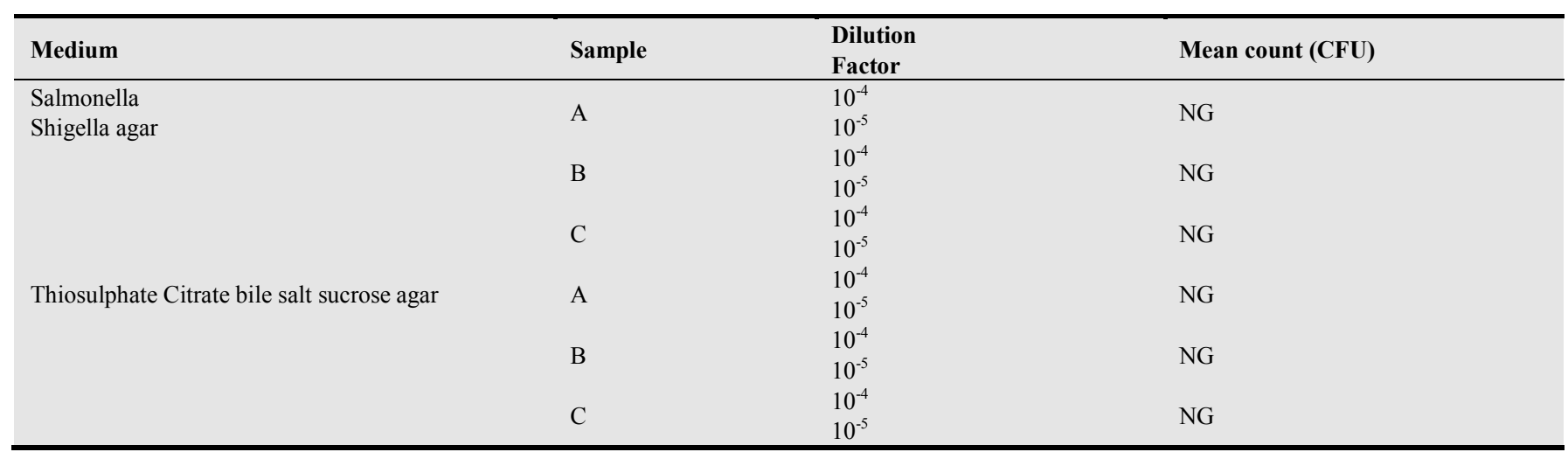

Legend: $\mathrm{NG}=$ No Growth 
Table 6. Isolates from specific sample points.

\begin{tabular}{|c|c|c|c|}
\hline Isolates & & & \\
\hline & $\mathrm{A}$ & $\mathrm{B}$ & $\mathrm{C}$ \\
\hline Staphylococcus sp. & + & + & + \\
\hline Escherichia coli & + & + & + \\
\hline Pseudomonas sp. & + & + & + \\
\hline Bacillus sp. & - & + & + \\
\hline Proteous sp. & + & + & - \\
\hline
\end{tabular}

Table 7. Percentage of average bacteria count of the samples.

\begin{tabular}{llll}
\hline Sample Points & THBC & TCBC & FCBC \\
\hline A & 22.9 & 16.7 & 14.7 \\
B & 33.3 & 29.1 & 52.9 \\
C & 43.8 & 54.2 & 32.4 \\
\hline
\end{tabular}

Table 8. Morphological and Microscopic characteristics of fungi isolated from the samples.

\begin{tabular}{llll}
\hline Medium & Samples & Cultured characteristics & Microscopic characterization \\
\hline \multirow{2}{*}{ SSA } & A & Fluffy brown pigmentation & Hyphae small and irregular \\
& $10^{-4}$ & Purple brown to black & Hyphae relatively small and regular with district cross septa \\
$10^{-6}$ & Greyish green colony that is dense & Septate hyphae, brush like spore bearing structure \\
& B & Purple brown to black & Hyphae relatively small and irregular with distinc septa \\
$10^{-4}$ & Greyish green colour & Septate hyphae, brush like spore bearing structure with chain \\
& Conidia & Penicillium sp. \\
$10^{-4}$ & Purple brown to purpose black & Hyphae relatively small and regular with district septa \\
\hline
\end{tabular}

Table 1 shows the physiochemical parameters of the water samples. The total heterotrophic counts are shown in Table 2 while Table 3 shows the result of total coliform count obtained from sample. Table 4 shows values of the feacal coliform isolated with mid-stream having the highest number of count while upstream has the lowest number of counts. There was no observable growth of Samonella, Shigella and Vibro cholerae in their respective media as shown in Table 5. Identified bacterial isolates from specific sample collection points are as shown in Table 6 . Table 7 shows the percentage of the average bacteria counts of samples. The morphological characteristics of the fungi isolated from samples are shown in Table 8.

\section{Discussion}

The results obtained in this study agree with similar studies by other researchers who reported that heterotrophic bacteria are found in water and could be from human/animal wastes, runoffs, pasture, natural soil or plant bacteria, sewage and other unsanitary, practices [14, 15 16]. Runoffs, sewage and agricultural waste are usually high inorganic matter and nutrients and could cause increase in the microbial flora of the water bodies, thereby resulting in high heterotrophic bacteria counts [17]. The high number of bacteria recorded could be as a result of the increased surface area which exposes the water to contaminant as well as human activities like swimming, washing, dipping of dirty legs, hands and cans inside the stream while fetching water as also reported by $[18,19,20]$.
The water samples did not comply with the World Health Organization (WHO) [21] standards for total heterotrophic count of $1.0 \times 10^{-2}$ in $100 \mathrm{ml}$ of water. The total coliform counts for all samples were higher than WHO standard of zero MPN in $100 \mathrm{ml}$ for drinking and recreational water. According to [21], drinking water can be graded into four (4) categories depending on their most probable number (MPN) value. Water with MPN of zero (0) is excellent, MPN of $1-$ 3 is satisfactory, MPN of $4-10$ is suspicious and MPN above 10 is unsatisfactory. Water with MPN greater than 3 is not suitable for drinking [21].

The high coliform values obtained maybe an indication that the water samples were feacally contaminated as also reported in a similar study by [22]. The presence of E.coli, Kebslella, Enterobacter sp and other bacteria not only make water unsuitable for human consumption and usage but also pose serious health concerns [23]. Similar studies reported the presence of those bacteria in drinking water sources [24, 25] and attributed it to indiscriminate human and animal defecation and general poor sanitation.

Other bacteria isolated: Staphylococcus sp., Pseudomonas aeruginosa, Proteus sp. are also of public health importance. Enterobacter aerogenes isolated from the water samples are examples of non-feacal coliforms and can be found in vegetation and soil [26] which could have served as sources by which the pathogens entered the water. Counts greater than $10^{4}$ are considered unsatisfactory for Enterobacter sp. The fungal growth was also higher than WHO [21] and EPA [27] standards with fungi that are of possible public health concern isolated from all three samples. These imply that 
water from Oguta lake is microbiologically unfit for both drinking and recreational purposes.

The physiochemical parameters; sulphate, manganese, $\mathrm{pH}$, TDS, TSS, turbidity and appearance conform to WHO standards. However, conductivity, color, iron, lead, cadmium, odor and nitrite had values above the standard. The iron content is above the WHO standard of $0.05 \mathrm{mg} / 1$ [21]. Iron has corrosive property. It gives water a corrosive taste, and according to [28] can cause harm to humans if it exceeds the WHO permissive limit of $0.05 \mathrm{mg} / \mathrm{l}$. Lead content is higher than WHO standard of $0.05 \mathrm{mg} / \mathrm{l}$ and accumulation of lead at higher concentration has some severe consequences on physical and mental development, along with deficit in learning ability in infant as well as increase in blood pressure and kidney problem in adults [28]. Cadmium permissible limit as set by WHO [21] is $0.05 \mathrm{mg} / \mathrm{l}$ which is lower than the results from this study. This is also worrisome as high concentration of cadmium in water when consumed, has been reported to cause nausea, vomiting, diarrhoea, muscle cramps, salivation, and at high accumulation; senses disturbances, liver injury, convulsion, stuck and renal failure [29]. Accumulation of high concentration of nitrite also has adverse effect on man especially infants. High level of nitrite has also been reported to cause algal bloom, which is unhealthy for aquatic life. Nitrite is the main constituent of inorganic fertilizer, and must have seeped into the lake through agricultural runoff. The presence of these harmful elements at concentrations above internationally acknowledged permissive limits make the water body unfit for drinking and recreation.

\section{Conclusion}

It has been revealed that currently, the microbiological and physiochemical quality of water from the Oguta lake makes it unfit for drinking and recreational activities. Yet many unassuming people are found using the water body for both activities. The contaminants seem to have seeped into the water body via human activities and agricultural runoff. There is therefore serious need to control activities around the Lake to prevent microbial as well as harmful chemical contaminats which have public health implications.

\section{References}

[1] UNICEF, Global Water supply and sanitation Assessment, 2000 reporting WHO and UNICEF, USA.

[2] O. Y. Ababio, New School chemistry, PEP International press limited, 1990, P. $256-261$.

[3] G.O. Main, "Surface water treatment for Odi community in Bayelsa state. A case study of river Nile," unpublished project report.

[4] E. I. Chukwurah, Aquatic Microbiology, Etoba press limited: Onitsha, Nigeria, 2001.

[5] O. Oyodeji, P.O. Olutiola, and M.A. Munmola, "Microbiological quality of packaged Drinking water bran marked in Ibadan metropolis and Ile-Ife in South western," Nigeria African Journal of Microbial. Research , vol. 4(1), Pp. $96-102,2010$.

[6] H.E. Birmingham, L.A. Loa, N. Ivdayiminje, S. Nkurikiye, B. S. Horsh, J. G. Wells and M.S. Ijeming, "Epidemic Cholera in Burundi, patterns of transmission in the Gadat - rift valley lake region," Lancet, vol. 349, Pp. 981 - 983, 1997.

[7] E. Jawetz, J. L. Meinick and E.A. Adelberg, Medical microbiology (19 ${ }^{\text {th }}$ ed), Apputon and Lange, Honwalk: Connecticut, 1991.

[8] P.B. Kelly, K.S. Ndubani, P. Wchuto, N. A. Luo, R.A. Feldman and M.J. Parthing, "Cryptoparidiosis in adults in Lusaka, Zambia and its relationship to Oocyst contamination of drinking water," Journal of infectious disease, vol. 176, Pp.: $1120-1125,1997$.

[9] T. W. Hejkal, B. Koswick, R. L. Labolle, C. P. Gorba, V. Sanchez, G. Droesman, B. Hafkin and J.L. Meinick, "Viruses in a community water supply associated with an outbreak of gastroenteritis and infectious hepatitis," Journal of the American water association, vol. 14, Pp. 317 - 321, 1982.

[10] S. Bonjelloun, B. Bahbouhi, N. Bouchrat, L.A. Chericaoni, N. Had, J. Mahjour, and A. Bensumane, "Seroepidemiological study of an acute Hepatitis E. outbreak," Morocco. Research Virology, vol. 148, Pp. $279-283,1997$.

[11] C.O. Owuama and A. P. Uzoije, "Waste disposal and Ground Water quality in Owerri," Nigeria journal of Environmental systems, vol. 31(1), Pp. $69-79,2005$.

[12] APHA, Standard Methods for Examination of Water and Waste water $\left(20^{\text {th }}\right.$ Ed.), American Public Health Assoication: New York, 1998, Pp $81-85$.

[13] M. Cheesbrough, District laboratory practice in tropical countries, Part 2, Cambridge University Press: UK, 2004.

[14] M.O. Edema, A.M. Omonu and O. M. Fapotu, "Microbiological and physiochemical Analysis of different sources of drinking Water in Abeokuta, Nigeria," Nigerian Journal of. Microbiology, vol. 15(1), Pp. 57 - 61, 2001.

[15] S.W. Ibe and J. Okplonye, "Bacteria Analysis of Borehole Water in Uli Nigeria,” Afr. J. Appl. Env. Biol. 7: 116 - 119, 2005.

[16] E.W. Kiman - Muraat and A.M. Ngindu, "Quality or Water the slum Dwellers use: The case of a Kenyan Slum," Journal of Urban Health, vol. 84 (6), Pp. 829 - 838, 2007.

[17] O. Obiro, and M Aguda, "Bacteria community of Loachotate from a waste dump and an Adjacent stream," Journal of Appl. Science. Environmental. Mgt, vol. 6(2), Pp. 77 - 76, 2004.

[18] P. Welch, J. David, Clarke Tapo, Borstons, M.C. Dougaltia and A. A. Ade siyin, "Microbial sanitation of Water in Rural Communities of Trinidad," Pan Amor T. J. Public Health 8(3): $72-180,2000$.

[19] O. B. Shittu, J. O. Olaitan and T. S. Amusa, "Physiochemical and Bacteriological Analysis of Water used for drinking and swimming purposes in Abeokuta Nigeria," African Biomedical Research, 2: Pp. 285 - 290, 2008.

[20] A.V. Majula, G.K. Shankar and S.M. Preeti, "Bacteriological analysis of drinking water samples," Journal of Microbiology, Vol. 18 (1-2), Pp. 387 - 391, 2011. 
[21] WHO, Water sanitation and Health programme, Managing water on the home accelerated health gains from improved water sources. World health organization www.who.int. 2004. Accessed, 10th June 2014.

[22] A.O. Ajayi, and K.A. Akonal, "Distribution pattern of Enteric organisms in Lagos Lagoon,"African Journal of Biomedical Research, vol. 8 issue 3, pp. 163 - 168, 2005.

[23] WHO, Guidelines for analyzing water quality $4^{\text {th }}$ Edition. WHO press, ISBN $978-921,2011$.

[24] 1. O. Okonko, O.O. Adejoye, T. A., Ogunnusi, E.A. Fajobi and O.B. Shittu, "Microbiological and Physio-chemical analysis of different water samples used for domestic purposes in Abeokuta and Ojota Lagos state, Nigeria," African Journal of Biotechnology, vol.. 7(3), Pp. 617 - 621, 2008.
[25] J.O. Adejuwon and K. A. Adelakun, "Physiochemical and bacteriological analysis of surface water in Ewekoro local Governent Area of Ogun State Nigeria: Case study Lala, Yobo and Agodo Rivers," International. Journal. water Fes and Environment Engineering, vol. 4, (3), Pp. 66 - 72, 2012.

[26] T.D. Reynolds, and P.A. Ricard, Operations and Processes in environmental engineering publishing company, ( $\left.{ }^{\text {nd }} \mathrm{Ed}\right)$, Bosten, 1996.

[27] EPA, U.S. Environmental Protection Agency, "Recreational Water quality criteria," EPA $820-12$-061, 2012.

[28] T.B. Hoekman, "Heavy metal toxicology," http://www.heavy metals.html. October, 2000. Accessed $20^{\text {th }}$ April, 2015. 